\section{Szok Wielkiej Wojny - o traumie indywidu- alnej, traumie kulturowej oraz portretach gueules cassées we współczesnej literaturze brytyjskiej i francuskiej}

Anna Branach-Kallas

TEKSTY DRUGIE 2018, NR 4, S. 12-36

DOI: $10.18318 /$ td.2018.4.2

1.

W swych rozważaniach zebranych w The Trauma Question Roger Luckhurst łączy dyskurs traumy z rozwojem nowoczesności i kapitalizmu jako systemu, który charakteryzują wysokie ryzyko i nieprzewidywalne zagrożenia ${ }^{1}$. Genealogii traumy dopatruje się także w katastrofach kolejowych drugiej połowy XIX wieku. „Wstrząśnienia kręgosłupa" (railway spine), na które skarżyli się poszkodowani w wypadkach komunikacyjnych Brytyjczycy, domagając się odszkodowania, uczyniły z traumy kategorię medyczno-prawną, z którą mogły się zmierzyć jedynie dyskursy i instytucje nowoczesnego, zbiurokratyzowanego społeczeństwa statystycznego. Wypadki na kolei skonfrontowały całość społeczeństwa brytyjskiego z niebezpiecznymi konsekwencjami uprzemysłowienia, których skutków doświadczała dotąd głównie w fabrykach klasa robotnicza ${ }^{2}$. Warto tu odnotować koincydencję

1 R. Luckhurst The Trauma Question, Routledge, London-New York 2008, s. 213.

2 Tamże, s. 24-25.
Projekt został sfinansowany ze środków Narodowego Centrum Nauki przyznanych na podstawie decyzji numer DEC-2013/11/B/ $\mathrm{HS}_{2} / 02871$.
Anna Branach-Kallas

- dr hab., profesor Uniwersytetu Mikołaja Kopernika w Toruniu, anglistka, romanistka, kierownik Centrum Badań Kanadyjskich UMK. Interesuje się literaturą wojenną i postkolonialną, teorią traumy oraz komparatystyką literacko-kulturową. Ostatnio opublikowała Uraz przetrwania. Trauma i polemika z mitem pierwszej wojny światowej w powieści kanadyjskiej (2014). Kontakt: kallas@umk.pl 
zmian prawnych z rozwojem badań psychologicznych nad traumą prowadzonych m.in. przez Jeana-Martina Charcota, Pierre'a Janeta, Zygmunta Freuda i Josefa Breuera, którzy jednak postrzegali fascynujące ich zjawisko histerii przede wszystkim jako dolegliwość kobiecą ${ }^{3}$. Pierwsza wojna światowa miała radykalnie zmienić to genderowe podejście do traumy. Co istotne, choć współczesne nam zainteresowanie traumą badacze łączą głównie z Holokaustem, wojną w Wietnamie i ruchem feministycznym lat 70. XX wieku, skutki uboczne katastrofy dręczące żołnierzy i weteranów I wojny stanowią coraz bardziej istotny materiał badawczy w tej dziedzinie ${ }^{4}$.

Pierwsza wojna światowa jako zindustrializowany system przemocy i śmierci, w którym brutalność miała również charakter nieprzewidywalny, wpisuje się w model traumy wprowadzony przez Luckhursta. W czasie pięćdziesięciu dwóch miesięcy walk zbrojnych zginęło dziewięć i pół miliona żołnierzy, średnio 5600 dziennie ${ }^{5}$. Na początku konfliktu wielu alianckich żołnierzy uległo złudzeniu, że celem wojny jest obrona cywilizacji i religii chrześcijańskiej przed hordami bestialskich Hunów ${ }^{6}$. Wojna okopowa na froncie zachodnim okazała się jednak ciężką, anonimową pracą w opresyjnych strukturach armii, przypominających wydajny system produkcyjny stworzony przez kapitalizm. Czekając na bezimienną śmierć, żołnierze czuli się bezbronni wobec technologii masowego rażenia, wyzuci z poczucia honoru i chwały. Zdaniem Erica J. Leeda dla milionów mężczyzn uwikłanych w konflikt I wojna była bezpośrednim, cielesnym doświadczeniem nowoczesności. Dla tych, którzy spodziewali się tradycyjnej konfrontacji z wrogiem, sprawdzianu swych umiejętności w boju, okazji dla wykazania się męstwem

3 Tamże, s. 34-49. Zob. również J. Lewis Herman Przemoc. Uraz psychiczny i powrót do równowagi, przeł. A. Kacmajor, M. Kacmajor, Gdańskie Wydawnictwo Psychologiczne, Gdańsk 2007, s. 20-30. Reakcje na męską histerię w tym okresie komentuje Mark S. Micale w Hysterical Men: The Hidden History of Male Nervous Illness, Harvard University Press, Cambridge, MA 2008. Zob. również Traumatic Pasts: History, Psychiatry, and Trauma in the Modern Age, 1870-1930, eds. M.S. Micale, P. Lerner, Cambridge University Press, Cambridge 2001.

4 J. Herman Przemoc, s. 30-43; R. Luckhurst The Trauma Question, s. 49-75; J. Edkins Trauma and the Memory of Politics, Cambridge University Press, Cambridge 2003, s. 1.

5 D. Cohen The War Come Home: Disabled Veterans in Britain and Germany, 1914-1939, University of California Press, Berkeley-Los Angeles-London 2001, s. 1.

6 J.J. Becker, J. Winter, G. Krumeich, A. Becker, S. Audoin-Rouzeau Guerre et cultures 1914-1918, Armand Colin, Paris 1994, s. 7-9.

7 E.J. Leed No Man's Land: Combat and Identity in World War I, Cambridge University Press, Cambridge 1979, s. 193. 
i odwagą, jatka Wielkiej Wojny była źródłem rozczarowania i głębokiego szoku psychicznego. Radykalne wtargnięcie śmierci do życia i umysłów żołnierzy, zwane „wdrukowaniem śmierci” (death imprint), analizuje Jay Lifton, podkreślając, jak trudno je zasymilować, nie tylko ze względu na nagłość wydarzenia ekstremalnego, lecz również na przerażenie towarzyszące perspektywie własnej śmierci. Zdarzenie traumatyczne nie przystaje do podstawowych struktur poznawczych, które zostały utrwalone przez jednostkę w ciągu jej dotychczasowego życia. Wypracowanie nowego schematu umysłowego, który pozwoliłby na zrozumienie tego, co zaszło, może okazać się niemożliwe, gdyż nadmiar przemocy związany z wojną wykracza poza zdolności poznawcze człowieka ${ }^{8}$.

Wybuch I wojny doprowadził do kolizji czynników medycznych, prawnych i psychologicznych w zarządzaniu traumą. Skala urazów psychicznych zaskoczyła personel medyczny i dowódców wojskowych, wywołując swoisty kryzys poznawczy i etyczny. Pojęcia shell shock, obusite, Kriegszitterer - szoku artyleryjskiego - budziły poważne kontrowersje. Występujące u żołnierzy podobne do histerii symptomy podważały ideał męskości, obowiązujący przede wszystkim w klasach wyższych, zgodnie z którym oczekiwano od mężczyzn odwagi i opanowania emocjonalnego. Uznanie ich dolegliwości za stan chorobowy wymagało radykalnych zmian w podejściu do odpowiedzialności żołnierza za własne czyny oraz jego stosunku do przełożonych. Fenomen shell shock kwestionował więc sedno dyscypliny wojskowej. W związku z tym dane dotyczące urazów psychicznych żołnierzy utrzymywano w tajemnicy. Większość personelu medycznego uznała na początku wojny, że stan traumatyczny jest skutkiem fizycznego urazu układu nerwowego spowodowanego wybuchem lub hukiem ognia artylerii. Wkrótce udowodniono jednak, że przyczyną objawów takich jak zaburzenia pamięci, paraliż, niepohamowane drżenie ciała, tiki czy utrata wzroku lub słuchu, był w większości przypadków szok emocjonalny, którego żołnierze doświadczali w sytuacjach granicznych na froncie. Choć lekarze wprowadzili później nowe, bardziej adekwatne terminy dla określenia traumatycznych reakcji na stres bojowy, żołnierz dotknięty shell shock stał się symbolem okaleczonego przez wojnę społeczeństwa, popularnym zwłaszcza w świecie angielskojęzycznym .

8 R.J. Lifton The Broken Connection: On Death and the Continuity of Life, American Psychiatric Press, Inc., Washington-London 1996, s. 169-170.

9 B. Shephard A War of Nerves. Soldiers and Psychiatrists 1914-1994, Pimlicoe, London 2002, S. 18-32; E.J. Leed No Man's Land, s. 163-170; P. Lerner Historiographie de la psychiatrie de guerre, 
Należy jednak pamiętać, jak zaznacza Jay Winter ${ }^{10}$, że zjawiska shell shock nie rozumiano w dobie I wojny tak, jak my rozumiemy traumę dziś. Pacjentów cierpiących na zaburzenia traumatyczne traktowano jak symulantów i degeneratów, a metody leczenia rzadko były humanitarne, zwłaszcza w Niemczech i we Francji ${ }^{11}$. Najsłynniejszy dziś brytyjski neurolog i psychiatra czasów wojny ${ }^{12}$, W.H.R. Rivers, stosował wprawdzie terapię opartą na rozmowie, dążąc do przywrócenia utraconych wspomnień weteranów, lecz uważał, w przeciwieństwie do Freuda, że zaburzenia pamięci były efektem autosugestii pacjenta ${ }^{13}$. Choć I wojna, a zwłaszcza specyfika koszmarów i flashbacków, dręczących powracających z frontu mężczyzn, miały znaczący wpływ na refleksję Freuda dotyczącą traumy i melancholiii ${ }^{14}$, cierpiący na zaburzenia pamięci weteran Wielkiej Wojny nie był jeszcze wówczas ikoną "rozdartej osoby” charakterystycznej dla "kultury rany", jak postrzegają go dziś zachodni badacze kultury ${ }^{15}$. To w perspektywie współczesnej postać straumatyzowanego żołnierza na ziemi niczyjej, dręczonego przez okruchy pamięci, które odgrywają rzeczywistość frontu, jednocześnie uniemożliwiając dostęp do przeszłości, jawi się, jak sugeruje Cathy Caruth, jako ucieleśniony symbol historii I wojny, która przywołuje wspomnienia kataklizmu, a jednocześnie wymazuje jego ślady ${ }^{16}$.

w: Histoire culturelle de la Grande Guerre, red. J-J. Becker, Armand Collin, Paris 2005; J. Winter Shell Shock, w: The Cambridge History of the First World War, Vol. 3: Civil Society, ed. J. Winter, Cambridge University Press, Cambridge 2014.

10 J. Winter Shell Shock, s. 317.

11 B. Shephard A War of Nerves, s. 97-108.

W dużej mierze za sprawą literatury, wspomnień z leczenia w szpitalu w Craiglockhart poety brytyjskiego Siegfrieda Sassoona oraz współczesnej fikcyjnej wizji relacji między tym ostatnim a Riversem stworzonej przez słynną pisarkę Pat Barker w powieści z 1991 roku Regeneration. Zob. P. Barker Odrodzenie, przeł. E. Krasińska, Warszawa 1998.

13 A. Young The Harmony of Illusions: Inventing Post-Traumatic Stress Disorder, Princeton University Press, Princeton 1997, s. 83.

14 Wojna zainspirowała refleksje Freuda ujęte m.in. w Aktualnych uwagach o wojnie i śmierci (1915), Żałobie i melancholii (1917) oraz Poza zasadą przyjemności (1920).

15 Zob. M. Seltzer Kultura rany, przeł. A. Rejniak-Majewska, w: Antologia studiów nad trauma, red. T. Łysak, Universitas, Kraków 2015, s. 351.

16 C. Caruth Literature in the Ashes of History, The John Hopkins University Press, Baltimore 2013, s. 78-81. To powstały w latach międzywojennych Człowiek imieniem Mojżesz a religia monoteistyczna (1939) Freuda zainspirował Caruth do klasycznych już dziś w teorii traumy rozważań na temat kryzysu świadectwa i aporii świadomości historycznej. Zob. C. Caruth Unclaimed Experience:Trauma, Narrative, and History, The Johns Hopkins University Press, Baltimore-London 1996. 
2.

Jak podkreśla Trudi Tate, odnosząc się do społeczeństw Europy Zachodniej i Ameryki Północnej, podczas wojny nie tylko żołnierze, ale i cywile nie potrafili zracjonalizować tego, co się wokół nich działo. Stali się ofiarą zmasowanej propagandy, kłamliwych doniesień prasowych, w których zatajano prawdziwą liczbę poległych oraz manipulowano danymi statystycznymi" ${ }^{17}$. Ponadto skala strat ludzkich była tak ogromna, że naznaczyła całe społeczeństwa i przyczyniła się do rozwoju narracji upamiętniania, takich jak brytyjski mit lost generation, zgodnie z którym w okopach I wojny zginęło całe pokolenie Brytyjczyków ${ }^{\mathbf{1 8}}$, czy też kanadyjskie i australijskie mity założycielskie, wedle których, choć okupiona niezmiernym poświęceniem, wojna udowodniła niezależność dominiów od Matki Brytanii ${ }^{19}$. „Kult żałoby”, jaki zdaniem Jaya Wintera rozwinął się po wojnie w całej Europie, był próbą ukojenia cierpienia po utracie najbliższych, przedwcześnie przerwaną przez wybuch drugiego globalnego konfliktu ${ }^{20}$. Liczne przypadki melancholii wśród matek, małżonek, sióstr, ojców, braci i dalszych krewnych poległych świadczą o nieprzepracowanej traumie ${ }^{21}$. Ważną rolę w rytuale żałoby odgrywały pomniki oraz pielgrzymki na pola bitew i cmentarze wojenne ${ }^{22}$. Fenomen „wspólnot żałoby"23 stworzonych przez ludzi, którzy nie byli ze sobą spokrewnieni, lecz którzy ze względu na swe dramatyczne przeżycia wojenne potrafili się zrozumieć

17 T. Tate Modernism, History and the First World War, Manchester University Press, ManchesterNew York 1998, s. 1, 41-43. $88 \%$ żołnierzy brytyjskich powróciło z frontu do domu. Zob. N. Ferguson cyt. za J. Edkins Trauma and the Memory of Politics, s. 22. J.F. Vance Death so Noble: Memory, Meaning and the First World War, University of British Columbia Press, Vancouver 1997; G. Seal Inventing Anzac: The Digger and National Mythology, University of Queensland Press, St Lucia 2004. J. Winter Sites of Mourning, Sites of Memory: The Great War in European Cultural History, Cambridge University Press, Cambridge 1996, s. 54-77.

21 J. Damousi Mourning Practices, w: The Cambridge History of the First World War, Vol. 3, s. 365. S. Audoin-Rouzeau i A. Becker wprowadzili termin circles of mourning, kręgi żałoby, starając się uporządkować jednostki dotknięte żałobą, podczas I wojny i po jej zakończeniu, poczynając od najbliższej rodziny poległych, po dalszych krewnych i przyjaciół. Zob. S. Audoin-Rouzeau, A. Becker 14-18: Understanding the Great War, trans. C. Temerson, Hill and Wang, New York 2014, s. 207-209. 
i wspierać, jest dowodem na powstanie w latach powojennych nowych form koegzystencji społecznej opartej na traumie.

Konflikt lat 1914-1918 można ująć w kategoriach nagłego, wielopłaszczyznowego kryzysu, charakterystycznego dla okresu transformacji ${ }^{24}$. Oprócz ludobójczego wymiaru kataklizmu wymienić należy takie elementy jak radykalne zmiany w funkcjonowaniu rodzin i społeczeństw, przemiany tożsamościowe żołnierzy, wielomilionowe migracje, reorganizacja ekonomiczna i polityczna, a także niezwykłe tempo tych przeobrażeń. Kryzysu, a raczej kryzysów, możemy doszukiwać się także w świecie kultury. Aby zapobiec krytyce propagandy wojennej w trakcie wojny, w wielu krajach wprowadzono ostrą cenzuręi i ustawy kontrolujące publiczne wypowiedzi, w tym działalność literacką i artystyczną. Organizacje pacyfistyczne, związki zawodowe, a także ruch feministyczny poddano szczególnie wnikliwej obserwacji. Na przykład w Wielkiej Brytanii zapanowała ogólna niechęć do sztuki modernistycznej, utożsamianej z twórczością niemiecką i dewiacją seksualną. Brytyjscy patrioci bezwzględnie potępiali naukę i muzykę niemiecką - grano tylko brytyjskie utwory. Wojna lat 1914-1918 toczyła się więc także na froncie domowym, gdyż uznano, że podwaliny tożsamości narodowej są zagrożone ${ }^{25}$. Pod wpływem wydarzeń ekstremalnych i swoistego przemieszczenia obowiązujących dotąd znaczen' ${ }^{26}$, kryzys światopoglądowy, epistemologiczny i afektywny dotknął miliony ludzi.

W trakcie wojny i po jej zakończeniu nastąpiło zatem tarcie dyskursów i rozbieżnych interpretacji konfliktu, charakterystyczne dla traumy kulturowej, która "ma miejsce wówczas, gdy członkowie zbiorowości czują, że poddani zostali straszliwemu wydarzeniu, pozostawiającemu nieusuwalne ślady na ich grupowej świadomości, na zawsze naznaczającemu ich wspomnienia oraz zmieniającemu ich przyszłą tożsamość w fundamentalny i nieodwołalny sposób"27. W latach powojennych, wobec masowej idealizacji poległych

24 P. Sztompka The Trauma of Social Change: A Case of Postcommunist Societies, w: J.C. Alexander, R. Eyerman, B. Giesen, N.J. Smelser, P. Sztompka Cultural Trauma and Collective Identity, University of California Press, Berkeley-Los Angeles-London 2004, S. 156.

25 S. Hynes A War Imagined: The First World War and English Culture, The Bodley Head, London 1990, s. 57-96.

26 J.C. Alexander Trauma kulturowa i tożsamość zbiorowa, w: Znaczenia społeczne. Studia z socjologii kulturowej, przeł. S. Burdziej, J. Gądecki, Nomos, Kraków 2010, s. 204. Rozdział ten jest wprowadzeniem do przełomowej książki definiującej pojęcie traumy kulturowej, J.C. Alexander, R. Eyerman, B. Giesen, N.J. Smelser, P. Sztompka Cultural Trauma and Collective Identity.

27 J.C. Alexander Trauma kulturowa i tożsamość zbiorowa , s. 195. 
w krajach takich jak Francja czy Wielka Brytania, weterani czuli się często lekceważeni - poniesione przez nich ofiary nie spotykały się z należnym szacunkiem ze strony państwa i cywilów, co prowadziło do postaw kontestacyjnych i roszczeniowych. Twórcy literatury antywojennej, którzy często brali aktywny udział w walkach, ujmowali wojnę jako pozbawioną sensu rzeź, co budziło moralny sprzeciw pogrążonych w żałobie cywilów, dla których ofiary poniesione w czasie wojny miały moc odkupienia, a pamięć o poległych była święta ${ }^{28}$. Dla obu grup wojna stanowiła cezurę, oddzielającą świat przedwojennych ideałów od mrocznego uniwersum wartości materialnych, które się z niej wyłoniło. W tej perspektywie eksperymenty awangardy modernistycznej można uznać za formę pisarstwa wojennego ${ }^{29}$, zarówno na poziomie treści, oddającej rozpad tradycyjnej etyki, jak i formy - trauma zaburza bowiem nie tylko sposób, w jaki postrzegamy czas, ale i jak go przedstawiamy. Echa traumy okopowej odnajdujemy w napięciach pomiędzy tym, co racjonalne a irracjonalne, charakterystycznych dla międzywojennych prądów artystycznych, takich jak dadaizm czy surrealizm ${ }^{30}$. Popularna wśród elit ironiczna symbolika modernistyczna, służąca radykalnej kontestacji znaczeń, koegzystowała jednak z tradycyjną retoryką upamiętniania, wykorzystującą konwencjonalne środki artystyczne w celu ukojenia bólu zwykłych ludzi dotkniętych tragedią ${ }^{31}$.

\section{3.}

Podczas gdy w przypadku jednostki trauma jest raną fizyczną lub/i psychiczną, w przypadku traumy kulturowej mówimy o „ranie” danej społeczności, charakteryzującą się dramatyczną utratą tożsamości zbiorowej32. Należy jednak pamiętać, jak podkreślają twórcy pojęcia, Jeffrey C. Alexander, Ron Eyerman, Neil J. Smelser, Bernard Giesen i Piotr Sztompka, iż trauma kulturowa nie jest jedynie efektem grupowego dyskomfortu i cierpienia. Kryzys społeczny musi stać się kryzysem kulturowym pod wpływem nowych

28 P. Poplawski English Literature in Context, Cambridge University Press, Cambridge 2008, s. 563.

29 Zob. T. Tate Modernism, History and the First World War.

30 J. Winter Shell Shock, s. 327.

31 J. Winter Sites of Mourning, Sites of Memory, s. 3-5.

32 R. Eyerman Cultural Trauma: Slavery and the Formation of African American Identity, w: Cultural Trauma and Collective Identity, s. 61. 
znaczeń - „roszczeń co do kształtu rzeczywistości społecznej” - stworzonych przez „nośników” traumy w sferze publicznej ${ }^{33}$. Kluczową rolę w tym procesie odgrywają politycy i działacze społeczni, ale również dziennikarze, pisarze, poeci, dramaturdzy, reżyserzy ${ }^{34}$. Trauma kulturowa nie tkwi zatem w ludzkich sercach czy umysłach, lecz w przestrzeni dyskursywnej między nimi ${ }^{35}$. Jest ona efektem ludzkich działań, procesów historycznych i kulturowych. Towarzyszą jej negatywne afekty, które prowadzą do reinterpretacji tożsamości i pamięci zbiorowej ${ }^{36}$. Jednostka reaguje na traumatyczne zdarzenie, uruchamiając szereg mechanizmów obronnych w celu przepracowania urazu; w przypadku traumy kulturowej za „przepracowanie” odpowiedzialne są grupy społeczne ${ }^{37}$. Nie oznacza to jednak, że określona trauma dotyka wszystkich ludzi w danej społeczności - pewne interpretacje zdarzeń przyjmują formę metanarracji ${ }^{\mathbf{3 8}}$. Jako przykład wymienić można skompromitowaną w latach późniejszych, lecz dominującą w Niemczech po I wojnie światowej interpretację konfliktu w kategoriach narodowej hańby. Innym przykładem jest brytyjski mit Wielkiej Wojny jako porażki (futility myth), pozbawionej sensu hekatomby, który wykształcił się głównie za sprawą poetów wojennych i mimo wysiłków historyków utrzymuje się w Wielkiej Brytanii do dziś. W tej grupie metanarracji można również umieścić polski dyskurs niepodległościowy, który przyćmił inne narracje na temat zawieruchy wojennej39.

Alexander wymienia cztery wymiary przedstawień, które są niezbędne dla stworzenia przekonującej „,ramy kulturowej klasyfikacji”, nowej opowieści wzorcowej, mającej na celu udowodnić szerszej publiczności, że doświadczyła

J.C. Alexander Trauma kulturowa i tożsamość zbiorowa, s. 204. Hołdując podejściom konstruktywistycznym, Alexander posuwa się czasem do radykalnych stwierdzeń, które niosą za sobą ryzyko podważenia ontologicznego wymiaru traumy.

N.J. Smelser Psychological Trauma and Cultural Trauma, w: Cultural Trauma and Collective Identity, s. 38; J.C. Alexander, E. Butler Breese On Social Suffering and Its Cultural Construction, w: Narrating Trauma: On the Impact of Collective Suffering, ed. by R. Eyerman, J.C. Alexander, E. Butler Breese, Paradigm Publishers, Boulder-London 2013, s. xxii.

I. Spasić The Trauma of Kosovo in Serbian National Narratives, w: Narrating Trauma, s. 99. N.J. Smelser Psychological Trauma and Cultural Trauma, s. 36; R. Eyerman Cultural Trauma, s. 60. N.J. Smelser Psychological Trauma and Cultural Trauma, s. 39. J.C. Alexander Trauma kulturowa i tożsamość zbiorowa, s. 209.

Heterogeniczność tych narracji omawia M.J. Olszewska w Człowiek w świecie Wielkiej Wojny. Literatura polska z lat 1914-1919 wobec I wojny światowej. Wybrane zagadnienia, Wydział Polonistyki UW, Warszawa 2004. 
traumy. Są to charakter cierpienia, charakter ofiary, relacja między ofiarami traumy a szerszą publicznością oraz przypisanie odpowiedzialności ${ }^{40}$.

- Zastanawiając się nad charakterem cierpienia, pytamy o to, co się faktycznie stało: ilu ludzi zginęło w czasie Wielkiej Wojny? W jaki sposób? Czy miało to sens? Jak doszło do tego, iż najbardziej rozwinięte narody Europy zaangażowały się w okrutną jatkę? Jakie były podobieństwa i różnice między frontem wschodnim a zachodnim? Czy żołnierze wierzyli w hasła propagandy, czy czuli, że są wykorzystywani do nikczemnych celów? Czy wojna musiała trwać tak długo? Jeśli miał miejsce upadek znaczeń, na czym dokładnie polegał?

- Charakter ofiary określa, którą grupę dotknęło cierpienie. Czy cywile także doznali urazu? Czy kobiety również były ofiarami traumy? Czy wśród ofiar wojny można wymienić prześladowanych w tym okresie obdżektorów? Czy wśród żołnierzy-weteranów były grupy, które poniosły poważniejsze konsekwencje? Czy zostali wynagrodzeni za swój trud? Jakie były mechanizmy koercji w Europie, Ameryce i krajach kolonialnych?

- Relacja między ofiarami traumy a szerszą publicznością jest często krucha i sporna. Celem nośników traumy jest zatem doprowadzić do tego, aby większa część zbiorowości dostrzegła związek między sobą a ofiarami traumy i się z nimi utożsamiła. W trakcie I wojny cywile często postrzegali żołnierzy jako zinfantylizowanych, niebezpiecznych dla ogółu barbarzyńców. Weteranów traktowano z nieufnością, a ich okaleczone ciała i umysły, w których czas wojny zlewał się z czasem pokoju, postrzegano w kategoriach abiektu. Organizacje weteranów w Europie Zachodniej walczyły o zmianę tej postawy, uznanie ich poświęcenia i nadanie im przywilejów należnych bohaterom. Niektóre grupy pozostały jednak na marginesie społeczeństwa i nie doczekały się współczucia większości, skazane na samotne cierpienie.

- Przypisanie odpowiedzialności za poniesione krzywdy, czyli ustalenie tożsamości sprawcy, stanowi kluczowy element w procesie konstrukcji traumy. Jakie były przyczyny konfliktu lat 1914-1918? Kto ponosi odpowiedzialność za wybuch I wojny? Niemcy czy kraje 
alianckie ${ }^{41}$ Czy to nie rządy konkretnych państw są winne śmierci tysięcy swych obywateli? Czy cywile, kobiety i starsi mężczyźni, którzy uniknęli poboru, nie wykazali się obojętnością wobec cierpienia młodych mężczyzn na froncie? Czy odpowiedzialnością za śmierć rekrutów z kolonii nie należy obarczać, bardziej niż żołnierzy wroga, kolonialnych metropolii?

Rekonstrukcja pamięci o traumatycznych wydarzeniach, podobnie jak proces przepracowania traumy indywidualnej, często zajmuje dużo czasu. Pomniki, muzea, rytuały upamiętniania, literatura, film, sztuka, służą rekonstrukcji tożsamości zbiorowej, zobiektywizowaniu „lekcji traumy”, ukojeniu bólu i „uspokojeniu” społeczeństw. Cytując Alexandra, „spirala znaczenia ulega spłaszczeniu, afekt i emocja stają się mniej gorące, a zaabsorbowanie sakralnością i skażeniem słabnie. [...] Nowa zbiorowa tożsamość zostaje zakorzeniona w świętych miejscach i ustrukturyzowana w rytualną rutynę"42. Zinstytucjonalizowanie traumy kulturowej łączy się często z poczuciem ulgi i inicjuje proces zapominania. W przypadku tych grup społecznych, których cierpienie nie zostało uznane, przepracowanie traumy może stać się jednak zadaniem dla kolejnych pokoleń. „Praca nad znaczeniem” często przebiega wówczas w twórczości artystycznej, a jej „celem jest wywołanie identyfikacji w wyobraźni oraz emocjonalnego katharsis"43. Współczesny odbiorca staje się w ten sposób świadkiem drugiego stopnia odzyskanej traumy, a świadectwo doznanego w przeszłości cierpienia nasuwa istotną refleksję na temat ciągłości pewnych historycznych zdarzeń oraz luk w kulturach upamiętniania. Przypominając zapomniane, fragmentaryczne, traumatyczne historie sprzed lat, utwory te dążą do poszerzenia kręgu solidarności i znaczenia słowa „my" ${ }^{\text {"44 }}$. To nie same wydarzenia traumatyczne, lecz narracje ich dotyczące budzą lęk i/lub współczucie ${ }^{45}$. Gdy brak autentycznych źródeł historycznych, tylko twórczość literacka i artystyczna, poprzez swój potencjał empatii, jest w stanie wypełnić luki w naszym obrazie przeszłości, ostrzegając przed moż-

41 W tym zakresie warto wspomnieć opublikowaną niedawno w przekładzie polskim przełomową pracę C. Clarka Lunatycy. Jak Europa poszła na wojnę w roku 1914, przeł. M. i T. Fiedorek, Wydawnictwo Akademickie "Dialog", Warszawa 2017.

J.C. Alexander Trauma kulturowa i tożsamość zbiorowa, s. 216.

Tamże, s. 210.

J.C. Alexander, S.M. Dromi Trauma Reconstruction and Moral Restriction: The Ambiguity of the Holocaust for Israel, w: Narrating Trauma, s. 109. 
liwą powtórką traumatycznych wydarzeń. Estetyczny i etyczny wymiar są tu istotniejsze niż wierne odtworzenie faktów historycznych ${ }^{46}$.

\section{4 .}

Wśród licznych ofiar I wojny światowej, gueules cassées, żołnierze o okaleczonych twarzach, zajmują miejsce wyjątkowe. Ich losy zyskały uwagę historyków i kulturoznawców w ostatniej dekadzie XX wieku ${ }^{47}$. Jeszcze do niedawna w centrum zainteresowania znajdowały się raczej heroiczne dokonania wybitnych chirurgów twarzowo-szczękowych, takich jak Harold Gillies z Queen's Hospital w Sidcup czy Hippolyte Morestin z Val-de-Grâce w Paryżu.Ten punkt widzenia pozwalał uwypuklić triumf nauki i postępu, pozostawiając w cieniu destrukcyjną potęgę Wielkiej Wojny ${ }^{48}$. Choć brak dokładnych danych statystycznych, nie ulega wątpliwości, że twarz żołnierza była szczególnie narażona na urazy podczas wojny okopowej. Pionierzy chirurgii rekonstrukcyjnej poddawali rannych licznym operacjom i przeszczepom, starając się usprawnić utracone funkcje, takie jak mowa czy przeżuwanie pokarmów, lecz ich wygląd w wielu przypadkach nadal pozostawał odrażający. Samo przyjęte powszechnie we Francji określenie gueule cassée podkreśla nieludzką przemianę okaleczonego mężczyzny: $w$ dosłownym tłumaczeniu oznacza ono "rozbitą mordę", a termin gueule używany jest w języku formalnym w odniesieniu do zwierząt. W Wielkiej Brytanii rany twarzy postrzegane były jako „wizualny afront", a dotkniętych nimi żołnierzy opisywano w kategoriach potworności i utraty człowieczeństwa ${ }^{49}$. Pacjenci o uszkodzonych twarzach spędzali w szpitalu długie miesiące, a nawet lata nie tylko ze względu na skomplikowane leczenie tych urazów, lecz także negatywny odbiór społeczny ich wyglądu oraz kryzys psychiczny przez nie wywołany ${ }^{50}$. Często przerażające okoliczności urazu powracały, prześladując ocalonych, zabiegi medyczne były

E. Butler Breese Claiming Trauma through Social Performance: The Case of Waiting for Godot, W: Narrating Trauma, s. 234.

7 Zob. S. Delaporte Les Gueules cassées. Les blessés de la face de la Grande Guerre, Éditions Noêsis, Paris 1996; M. Gehrhardt The Men with Broken Faces: Gueules Cassées of the First World War, Peter Lang, Bern 2015.

M. Gehrhardt The Men with Broken Faces, s. 9.

K. Feo Invisibility: Memory, Masks and Masculinities in the Great War, "Journal of Design History" 2007 no. 20.1, s. 20, https://doi.org/10.1093/jdh/eplo39 (2.02.2015).

Tamże, s. 20. 
dla nich źródłem bezgranicznego cierpienia, izolacja pogłębiała lęk przed powrotem do zwykłego życia, a okaleczona twarz na zawsze już miała przypominać o katastrofie.

Deformacja rysów twarzy budzi szczególny niepokój, gdyż twarz sama w sobie wydaje się zasadniczym elementem znaczącym ludzkiej tożsamości. Odgrywa centralną rolę w schemacie cielesnym, z jakim się identyfikujemy i który umożliwia nasze bycie w świecie. Ponieważ nowy wygląd jednostki radykalnie odbiega od wyobrażonego obrazu „ja”, okaleczenia twarzy stanowią źródło głębokiego urazu psychicznego ${ }^{51}$. Utrata twarzy postrzegana jest zatem jako utrata tożsamości. Rana jest więc w tym przypadku urazem fizycznym i psychicznym; naznaczając na zawsze rysy żołnierza, czyni z niego ponadto makabryczny spektakl, otwarty na interpretacje z zewnątrz. Jeśli zdefiniujemy traumę jako efekt działania czynników somatycznych, psychologicznych

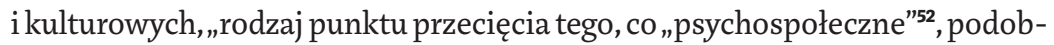
nie ująć można ranę twarzy: potworna, namacalna rana w tym przypadku jest źródłem rozszczepienia „ja” i wizualnym znakiem rozpadu podmiotowości.

Nagły powrót tematyki I wojny, który badacze obserwują w kulturze brytyjskiej i francuskiej od lat 8o. XX wieku, zaowocował również zainteresowaniem losami żołnierzy o okaleczonych twarzach wśród twórców literatury pięknej ${ }^{53}$. Zinterpretowane poniżej utwory Louisy Young, Pat Barker, Marca Dugaina i Pierre'a Lemaitre'a, wyróżnione licznymi nagrodami, cieszą się szczególnym uznaniem zarówno wśród czytelników, jak i wśród krytyków ze względu na oryginalność tematu i poruszające portrety weteranów ${ }^{54}$. Bohaterem powieści brytyjskiej pisarki Louisy Young My Dear, I Wanted to Tell You z 2011 roku, przetłumaczonej na język polski jako Kochanie chcę ci powiedzieć,

51 S. Henry Disfigurement and Visible Difference: The Impact upon Personal and Personality Development and The Implications for Therapy " Person-Centered \& Experiential Psychotherapies” 2011 no. 10.4, s. 276, http://dx.doi.org/10.1080/14779757.2011.626635 (2.04.2015).

53 Na temat przyczyn tej nagłej eksplozji literatury pierwszowojennej po prawie pięćdziesięciu latach nieobecności zob. A. Branach-Kallas, P. Sadkowski Comparing Grief in French, British and Canadian Great War Fiction (1977-2014), Brill/Rodopi, Leiden 2018, s. 1-11. re należą do bestsellerów. Barker uznawana jest za jedną z najwybitniejszych współczesnych pisarek brytyjskich. Do sukcesu powieści Dugaina i Lemaitre'a przyczyniła się również ekranizacja ich utworów: La chambre des officiers w 2001 roku (w reżyserii François Dupeyrona), Do zobaczenia w zaświatach w 2017 roku (w reżyserii Alberta Dupontela). Interpretowane tu powieści analizuję w szerszym kontekście w A. Branach-Kallas, P. Sadkowski Comparing Grief.., s. 12-51. 
jest młodziutki Riley Purefoy, który traci pół twarzy w wyniku eksplozji podczas bitwy pod Passchendaele. Sam moment urazu zostaje wyparty przez jego psychikę, ale okruchy przerażających wspomnień nękają go jeszcze wiele lat później. Poddany licznym zabiegom w szpitalu w Sidcup, bohater doznaje głębokiego rozszczepienia ego. Jego zdaniem skomplikowany proces rekonstrukcji, która ma przywrócić jego rysom ludzki wygląd, służy jedynie utracie człowieczeństwa. Kiedy po raz pierwszy ogląda swoją twarz po zdjęciu opatrunku, dochodzi do wniosku, że przypomina ona ziemię niczyją:

To w ogóle nie wyglądało jak twarz. [...] Szkarłatny krater z brzegiem z na wpół uformowanych ziemskich szańców, przewróconych stosów brudnych worków z piaskiem. Szare bruzdy i purpurowe obrzmienia, i czarny strup zwieszający się ponad nicością. Metalowa podpórka na brodę wyglądała jak umocnienia. Szwy między kawałkami ciała znaczyły jego twarz jak okopy. Kilka luźnych szwów jak drut kolczasty. ${ }^{55}$

Riley nie potrafi wyobrazić sobie powrotu do zwykłego życia - uważa, że stał się „kikutem, resztkami, połową człowieka" ${ }^{\text {, }}$, i pogrąża się w apatii, pragnąc umrzeć. Pytanie „kim jestem?” staje się kluczowym zagadnieniem w powieści.

Zmasakrowana twarz Rileya stanowi ponadto w jego własnych oczach wyraz dramatycznej przemiany, której doznał na froncie. Zdaniem Erica J. Leeda, wiedza, jaką żołnierz nabywa podczas wojny, jest swoistą cezurą, która oddziela go na zawsze od własnej przeszłości i świata cywilów. Świadomość tę i ukształtowane wokół niej ego trudno zintegrować, gdyż stanowią zaprzeczenie wszelkich wpajanych wcześniej poglądów i wartości ${ }^{57}$. Stając się zabójcą - „agresywnym wykonawcą woli narodu” - żołnierz wyrzeka się wcześniejszej tożsamości, co pozwala mu funkcjonować w nowej strukturze społecznej, jaką jest armia w warunkach wojny ${ }^{58}$. Przemiana Rileya wpisuje się zatem w proces, jaki badacze I wojny określają mianem brutalizacji: podlega jej nie tylko ciało żołnierza, przeszkolone w sztuce zabijania, lecz również

\footnotetext{
55 L. Young Kochanie chcę ci powiedzieć, przeł. E. Siarkiewicz, Prószyński i S-ka, Warszawa 2011, s. 271.

56 Tamże, s. 260.

57 E.J. Leed No Man's Land, s. 75.

58 Tamże, s. 113.
} 
jego psychika ${ }^{59}$. Będąc sprawcą okrucieństw, żołnierz nie może pozostać bez skazy - wojna sprawia, że zostaje na zawsze splamiony otaczającym go uniwersum śmierci i zniszczenia ${ }^{60}$. Utrata twarzy jest więc zdaniem Rileya karą za tę brutalną metamorfozę, karą za wszystkich Niemców, których zabił, i za śmierć towarzyszy broni, których pozostawił w mękach na ziemi niczyjej. Trauma polega tu ponadto nie tyle na braku środków językowych, niemożności werbalizacji, co na rozpadzie znaczeń, rozszczepieniu więzi między znaczącym a znaczonym ${ }^{61}$. Słowa takie jak wojna, lęk, przemoc znaczą dla weterana coś innego niż dla reszty społeczeństwa. Myśli on i mówi innym językiem, pozostając na zawsze uwięzionym w czasie wojny.

Poharatana twarz staje się w oczach bohatera metonimią hańby i wewnętrznej skazy. Jeśli w traumie „coś wpada w psychikę i powoduje jej «rozdarcie»"62, zaburzając granice jaźni, w powieści Young tym czymś jest sama wojna, która odmienia na zawsze bohatera. Trwale wyryta na jego twarzy, nie pozwoli mu nigdy zapomnieć: jeśli w doświadczeniu traumatycznym rozdarta psychika ciągle wynajduje tropy odnoszące się do katastrofalnego zdarzenia, twarz Rileya będzie mu nieprzerwanie o nim przypominać, bezustannie rozszczepiając jego jaźń. Kochanie chcę ci powiedzieć należy jednak do gatunku opowieści o traumie, które Dominick LaCapra określił jako „narracje harmonijne"63 - poprzez poświęcenie na rzecz innych Rileyowi udaje się „odzyskać twarz". Young opisuje pozytywną przemianę bohatera, którego doświadczenie traumatyczne motywuje do przyjęcia postawy posłanniczej. Wojna będzie jednak na zawsze $w$ nim obecna, a jego twarz pozostanie krępującym, ucieleśnionym „miejscem pamięci”64, przypominającym wszem i wobec o brutalnej przeszłości. Trauma wojny, wyryta na twarzy bohatera, naznacza bowiem całe społeczeństwo brytyjskie.

59 J.-J. Becker, J. Winter, G. Krumeich, A. Becker, S. Audoin-Rouzeau Guerre et Cultures 1914-1918, s. 7-9.

60 Zob. R.J. Lifton The Broken Connection, s. 176.

61 K. Tal Worlds of Hurt: Reading the Literatures of Trauma, Cambridge University Press, Cambridge 1996, s. 16. G.H. Hartman Wiedza traumatyczna i badania literackie, przeł. J. Burzyński, w: Antologia studiów nad traumą, s. 378.

63 D. LaCapra Writing History, Writing Trauma, The John Hopkins University Press, Baltimore-London 2001, s. 13.

64 M. Gehrhardt The Men with Broken Faces, s. 21. 
W opublikowanej w 2012 roku powieści Toby's Room brytyjskiej pisarki Pat Barker ten dyskomfort obejmuje tożsamość zbiorową. Jej bohaterka Elinor Brooks pracuje w Queen's Hospital w Sidcup z Henrym Tonksem, wybitnym chirurgiem i artystą. Jej funkcją jest szkicowanie okaleczonych twarzy pacjentów, aby wspomóc w ten sposób proces rekonstrukcji6. ${ }^{65}$. Kiedy Elinor udaje się pierwszy raz do szpitala, nie wie, jak patrzeć na poharatane twarze żołnierzy; ogarnia ją głęboki lęk i niepewność, czuje się głęboko zażenowana. Jej przyjaciel Kit Neville, który sam doznał obrażeń twarzy, jest świadom faktu, że okaleczeni weterani powinni pozostać w ukryciu, gdyż odczucia Elinor są charakterystyczne dla całego społeczeństwa. Suzannah Biernoff uważa, że podczas I wojny w Wielkiej Brytanii rany twarzy wywołały swoisty kryzys wizualny. Lekarze, pielęgniarki, rodzice, żony, dzieci nie byli w stanie spojrzeć prosto w twarz okaleczonego żołnierza. Wokół straumatyzowanych mężczyzn rozwinął się dyskurs niechęci i odrazy ${ }^{66}$. Monstrualność wojny, przynależna do świata frontu, wkraczała bowiem w ten sposób do świata cywilów, siejąc wśród nich popłoch.

Niechęć i odraza okazywane w powieści Barker okaleczonym żołnierzom stawiają pod znakiem zapytania ich bohaterskie dokonania na froncie, odbierając im prawo do poczucia dumy i uznania. Wyrazem przeświadczenia, że przemoc wojny powinna pozostać ukryta, są maski, które nakładają w powieści Barker weterani. Ukrywanie pod maską okrutnych skutków katastrofy wojennej prowadzi jednak do odrealnienia tragedii doznanej przez ofiary traumy oraz samego ich istnienia. Konieczność zakrywania poharatanej twarzy sprawia, że gueules cassées stają się tym bardziej nierealni dla siebie samych i dla zaniepokojonej ich obecnością wspólnoty, która tym samym tłumi dyskomfort wywołany wojenną katastrofą. W powieści Barker kryzys wizualny jest więc wyrazem kryzysu

65 Tonks współpracował z Gilliesem, tworząc diagramy w trakcie procesu rekonstrukcji twarzy pacjentów, a także pastele przedstawiające ich twarze przed i po operacji. W trakcie Wielkiej Wojny uważano, że rysunki i obrazy okaleczonych twarzy były bardziej autentyczne i wiarygodne niż czarnobiałe fotografie, gdyż op rócz niuansów kolorystycznych oddawały również pewną prawdę emocjonalną. Zob. S. Biernoff Flesh Poems: Henry Tonks and the Art of Surgery, "Visual Culture in Britain" 2010 no. 11.1, s. 35, http://dx.doi.org/10.1080/14714780903509979 (10.01.2015). Dzieło Tonksa udostępniono w 2007 roku na stronie archiwum Gilliesa, http://www.gilliesarchives.org.uk/tonkspastels.htm.

66 Jako bohaterów w przestrzeni publicznej przedstawiano kalekich weteranów, którzy utracili kończyny. S. Biernoff The Rhetoric of Disfigurement in First World War Britain, „Social History of Medicine" 2011 no. 24.3, s. 668-669, http://www.ncbi.n/m.nih.gov/pmc/articles/PMC3223959/ (29.01.2015). 
epistemologicznego i etycznego charakterystycznego dla momentów przełomowych w historii społeczeństw. Wojna stanowi tu źródło negatywnych afektów i poczucia zagrożenia dla spoistości wspólnoty oraz tożsamości jej członków, co jest wyznacznikiem tragedii narodowych postrzeganych w kategoriach traumy kulturowej ${ }^{\mathbf{6 7}}$.

Kiedy Elinor nawiązuje kontakt wzrokowy z okaleczonymi pacjentami, obawia się, że jej spojrzenie może wyrażać wstręt i przerażenie. Próbuje zatem przyglądać się im z boku, lecz jest świadoma, że taka postawa może również być zinterpretowana jako wyraz obrzydzenia. Fizyczna trauma doznana przez żołnierzy sprawia, że utrwalone zasady społecznej interakcji przestają obowiązywać. Rana, wydobywająca na wierzch ukryte tkanki i organy, stanowi źródło uprzedmiotowienia, które kłóci się z poruszającym wyrazem ludzkiego cierpienia widocznym w oczach mężczyzny. Napięcie między przedmiotem a podmiotem, ciałem a jaźnią, jest dla niej źródłem głębokiego dyskomfortu. Bohaterka musi zatem nauczyć się nie tylko patrzeć na okaleczoną twarz, ale również widzieć ukrytą za nią osobowość.

W Toby's Room Barker uwypukla zatem traumatyczną konfrontację z wojną kobiety-artystki, która, w przeciwieństwie do mężczyzn, nie może być bezpośrednim świadkiem ekstremalnych wydarzeń na froncie; która patrzy, ale nie rozumie tego, co widzi i szuka sposobów, żeby zmierzyć się z wojną twarzą w twarz. Ilustrując dylematy artystów wobec propagandy, Barker porusza również kwestię odpowiedzialności sztuki wobec katastrofy wojennej, ukazując, że artysta ma do wyboru jedną z dwóch postaw: wspieraną przez państwo opcję estetyzacji rzeczywistości, ukrycia traumy niczym okaleczonej twarzy żołnierza pod maską lub poszukiwania nowych środków estetycznych, wbrew obowiązującemu dyskursowi niechęci i odrazy, aby wyrazić niszczycielską siłę kataklizmu ${ }^{68}$. W powieści Barker poharatana twarz żołnierza porównywana jest do zniszczonego krajobrazu ziemi niczyjej - zdaniem bohaterów są to jedyne autentyczne obrazy wojny ${ }^{69}$. Co istotne, kontakt z okaleczonymi żołnierzami prowadzi do przemiany etycznej Elinor - zyskuje ona bowiem w ten sposób traumatyczną wiedzę na temat wojny, która pozwala jej pokonać odrazę oraz niechęć i okazać empatię okaleczonym mężczyznom.

67 N.J. Smelser Psychological Trauma and Cultural Trauma, s. 38-42.

68 A. Whitehead War and Beauty: The Act of Unmasking in Pat Barker's Toby's Room and Louisa Young's My Dear, I Wanted to Tell You, w: The Recovery of Beauty: Arts, Culture, Medicine, ed. by C. Saunders, J. Macnaughton, D. Fuller, Palgrave Macmillan, New York 2015, s. 225.

69 Pobrzmiewają tu echa Ziemi jałowej, poematu T.S. Elliota z 1922 roku. 
Tarcie między społeczną percepcją okaleczonej twarzy a zbiorową traumą gueules cassées, subtelnie zasygnalizowane przez Barker, zostało uwypuklone w powieści francuskiego pisarza Marca Dugaina z 1998 roku La chambre des officiers. Dla bohatera, Adriena, który uległ okaleczeniu w pierwszym dniu konfliktu i spędza całą wojnę w szpitalu Val-de-Grâce w Paryżu, rana twarzy oznacza radykalną transformację. Na oddziale szpitalnym nie ma żadnych luster, jednak gdy Adrien dostrzega w szybie okiennej zarys swojej zmasakrowanej twarzy, popada w głęboką depresję i miewa myśli samobójcze. Ponadto widzi własne zniekształcone rysy, niczym w lustrzanym odbiciu, w twarzach innych pacjentów. Dla nich wszystkich trauma - rana fizyczna, rana psychiczna - staje się źródłem podmiotowości.

Izolacja pacjentów na oddziale szpitala ma w powieści olbrzymie znaczenie. Jej celem jest nie tyle ochrona weteranów przed przykrym doświadczeniem, jakim może być reakcja przerażenia i wstrętu wśród cywilów na widok ich okaleczonych twarzy, co ochrona reszty społeczeństwa przed widokiem, który mógłby podkopać morale tak istotne w trakcie przedłużającej się wojny. Żołnierze skazani są zatem na długi pobyt w szpitalu z dala od swoich bliskich, co stanowi przykład swoistej „biopolityki traumy”, tzn. biurokratycznego zarządzania ludzkim nieszczęściem w trakcie Wielkiej Wojny. Jak zaznacza Peter Vermeulen, w tym przypadku „redukcja indywidualnej traumy liczy się znacznie mniej niż masowe zarządzanie traumą"70. Zamknięcie gueules cassées w Val-de-Grâce daje możliwość maksymalnej mobilizacji innych zasobów ludzkich.

Dzięki wysiłkom Adriena i jego towarzyszy wspólnota gueules cassées stara się jednak wpisać ranę twarzy w sieć znaczeń odmienną od dominującej narracji traumy. Dugain przywołuje tu autentyczne fakty - pacjenci szpitala Val-de-Grâce w Paryżu stworzyli bowiem system wsparcia, a następnie organizację weteranów nazwaną później l'Union des Blessés de La Face, która uznała ranę twarzy za wyraz największego poświęcenia dla kraju, a samych gueules cassées za walecznych patriotów ${ }^{71}$. Traumę jednostki zastąpiła w ten sposób tożsamość grupowa, również oparta na doświadczeniu traumatycznym - stanowiło ono jednak źródło nobilitacji weterana i swoistego etosu łączącego wspólnotę. Dugain ukazuje pracę nad znaczeniem cierpienia gueules

P. Vermeulen Biopolityka traumy, w: Antologia studiów nad trauma, s. 456.

71 W porównaniu z kontekstem brytyjskim i niemieckim była to jedyna organizacja o realnych wpływach, która upowszechniła pozytywny obraz gueules cassées wśród Francuzów. Zob. M. Gehrhardt The Men with Broken Faces, s. 123-173. 
cassées również w latach powojennych. Przerażająca odmienność weteranów "bez twarzy" ograniczała możliwość empatii szerszej publiczności. Dopiero gdy doznana przez nich trauma została przedstawiona w kategoriach cech pozytywnych, nastąpił we Francji zwrot w percepcji ich okaleczonych rysów. W przeciwieństwie do kontekstu brytyjskiego w metanarracji rządowych elit we Francji gueules cassées stali się ikoną bohaterskiego patriotyzmu, a po zakończeniu wojny ich obecność była wielce pożądana podczas wszelkich uroczystości państwowych ${ }^{72}$. W La chambre des officiers, choć Adrien zostaje zaproszony przez samego Clemenceau na uroczystość podpisania traktatu wersalskiego, ma trudności ze znalezieniem pracy ze względu na swą okaleczoną twarz. Z czasem bohater akceptuje fakt, że powrót do dawnego życia nie będzie możliwy. To wspólnota gueules cassées jest odtąd jego prawdziwą rodziną, odizolowaną od reszty społeczeństwa, a nawet od innych weteranów. Trauma stanowi zatem w powieści formę bycia społecznego opartego na ranie, które jest źródłem wyobcowania, lecz jednocześnie wyjątkowej, hermetycznej więzi grupy uznanej za elitę moralną ${ }^{73}$.

Intrygująca jest także zarysowana przez Dugaina analogia pomiędzy społecznością gueules cassées a społecznością Żydów w latach 30. we Francji. Scena, w której Adrien staje się przedmiotem zaczepek grupy dzieci, stanowi lustrzane odbicie obrazów znęcania się nad Żydami. Po wybuchu II wojny Adrien pomaga swemu przyjacielowi ze szpitala, który jest Żydem, zorganizować kryjówkę w domu innego weterana w Bretanii. Spędzają wspólnie trzy lata wojny, powracając do rutyny z Val-de-Grâce; te lata izolacji - w szpitalu i na farmie - zlewają się w powieści w jeden ciąg ${ }^{74}$. Porównanie z ofiarami Holokaustu wzmacnia znaczenie traumy zbiorowej gueules cassées w powieści Dugaina - obie grupy jawią się więc jako „wymienne ofiary nowoczesności”75. Celem tak ustanowionej analogii nie jest jednak zrównanie losu Żydów i okaleczonych weteranów, lecz pełniejsze zrozumienie odmiennych doświadczeń

72 Tamże, s. 269.

73 K. Erikson Notes on Trauma and Community, w: Trauma: Explorations in Memory, ed. by C. Caruth, The Johns Hopkins University Press, Baltimore-London 1995, s. 186.

74 "Nasz wybuch śmiechu położył kres siedmiu latom osobliwej izolacji, jakbyśmy grali w dziwnej sztuce w dwóch aktach, pierwszym osadzonym na oddziale szpitala wojskowego, drugim w piwnicy bretońskiej farmy" [przeł. A.B.-K.]. M.Dugain La Chambre des officiers, JC Lattès, Paris 1998, s. 169.

75 M. Silverman Palimpsestic Memory: The Holocaust and Colonialism in French and Francophone Fiction and Film, Berghahn, New York-Oxford, 2013, s. 14. 
traumy splątanych ze sobą w historii Francji - niczym w palimpseście jedna trauma wyziera spod kolejnej ${ }^{76}$. Dugain tworzy swoistą wizję solidarności, którą za Michaelem Rothbergiem możemy określić jako „solidarność zróżnicowaną"; powstała oś porównania, unikając hierarchizacji, dąży do sprawiedliwości historycznej i społecznej" ${ }^{77}$. Jednakże, korelacja pomiędzy okaleczoną twarzą a gwiazdą Dawida świadczy również o tym, że proces traumy kulturowej nie został doprowadzony do końca: lekcje traumy nie zostały upamiętnione, nie poszerzono także definicji moralnej odpowiedzialności ${ }^{78}$. Paralela ta wskazuje raczej na nieustanną potrzebę stygmatyzacji wybranych grup społecznych. Interesujące jest to, że w La chambre des officiers są nimi bohaterowie I wojny oraz ofiary drugiego globalnego konfliktu. Dugain zdaje się w ten sposób sugerować, że choć wyparty, tragiczny los obu grup wpłynął na doświadczenie francuskiej tożsamości narodowej. Zarysowana wizja solidarności wydaje się niemniej istotna wobec trudnego procesu akceptacji przez Francuzów ich roli w Holokauście ${ }^{79}$. Splątane ze sobą w powieści traumy Żydów i gueules cassées kreują utopijną wizję, „poszerzają obszar społecznego porozumienia i współczucia oraz dostarczają ważnych dróg dla nowych form społecznego zjednoczenia"80.

W wyróżnionej nagrodą Goncourtów powieści Au-revoir là-haut Pierre'a Lemaitre'a z 2013 roku, przetłumaczonej na język polski jako Do zobaczenia w zaświatach, portret okaleczonego weterana służy bardziej radykalnej kontestacji wojny, kwestionując porządek symboliczny, który reguluje tożsamość

76 Tamże, s. 5.

77 W swej wizji pamięci wielokierunkowej Rothberg uczula czytelnika na wszechobecność analogii do Zagłady, sugerując, że niektóre z nich mogą utrwalać antagonizmy, natomiast inne pozwalają je neutralizować i lepiej zrozumieć zestawione ze sobą historie i konflikty. M. Rothberg Między Paryżem a Warszawq. Pamięć wielokierunkowa, etyka i odpowiedzialność historyczna, w: Od pamięci biodziedzicznej do postpamięci, przeł. T. Bilczewski, A. Kowalcze-Pawlik, red. T. Szostek, R. Sendyka, R. Nycz, Wydawnictwo IBL PAN, Warszawa 2013, s. 169-178. Na temat porównań do Zagłady w kulturze francuskiej zob. M. Silverman Palimpsestic Memory; M. Rothberg Pamięć wielokierunkowa. Pamiętanie Zagłady w epoce dekolonizacji, przeł. K. Bojarska, Wydawnictwo IBL PAN, Warszawa 2016.

78 J.C. Alexander Trauma kulturowa i tożsamość zbiorowa, s. 220-221.

79

Należy podkreślić, że powieść opublikowano w latach 90., kiedy to zainteresowanie historią gueules cassées we Francji zbiegło się z obsesyjną reinterpretacją roli Francji podczas II wojny światowej, a szczególnie postawy Francuzów wobec Holokaustu. Zob. M. Rothberg Pamięć wielokierunkowa...

80 J.C. Alexander Trauma kulturowa i tożsamość zbiorowa, s. 217. 
indywidualną i społeczną. Akcja powieści rozgrywa się w latach 1918-1920 we Francji, a jej bohaterami są dwaj weterani Wielkiej Wojny, Albert Maillard i Édouard Pradelle. Ratując kolegę przysypanego żywcem podczas eksplozji na ziemi niczyjej, Édouard sam doznaje poważnych obrażeń. Jego twarz jest tak poważnie okaleczona, że mężczyzna próbuje popełnić samobójstwo. Poddany licznym operacjom, rezygnuje jednak z kolejnych interwencji chirurgicznych. Utracił język a zatem i zdolność mowy, krztusi się nadmiarem śliny, a z otchłani poniżej jego nosa wydobywa się smród procesów trawiennych. Postanawia ukryć się z Albertem w Paryżu, przyjmując fałszywą tożsamość zmarłego przed nim w szpitalu pacjenta. Podejmując się dorywczych prac, Albert utrzymuje towarzysza, który uratował mu życie.

Utrata twarzy wywołuje u Édouarda radykalne rozszczepienie tożsamości. Teraźniejszość postrzega jakby przez mgłę, przyszłości nie potrafi sobie wyobrazić, a z przeszłości zostały mu jedynie strzępy wspomnień. Twarze bliskich osób, ojca, matki, siostry, kolegów, zacierają się w jego pamięci, jak gdyby utrata własnej twarzy wywołała ogólny kryzys egzystencjalny dotyczący natury człowieczeństwa: „Twarze ich wszystkich, włącznie z jego własną, zniknęły, żadna się nie ostała. Czego uchwycić się w takim świecie pozbawionym twarzy, z kim walczyć? Pozostały tylko zastępy bezgłowych postaci"81. Portret nabiera głębszego znaczenia w konfrontacji z lacanowską psychoanalizą, w której faza lustra stanowi podstawę ukształtowania ego. Przeżyta trauma uświadamia Édouardowi fantazmat pełni ludzkiej podmiotowości. Traci swój wyobrażeniowy wizerunek, gdyż nie potrafi się rozpoznać w lustrzanym odbiciu:

Powiadają, że do wszystkiego można się przyzwyczaić, otóż nie, Édouard przyzwyczaić się nie mógł. Ilekroć poczuł w sobie dość siły, stawał przed lustrem i przyglądał się swojej twarzy, nie, nie było ani trochę lepiej, z tym gardłem na przestrzał, pozbawiony szczęki i języka nigdy nie odzyska nawet namiastki ludzkiego wyglądu. I z tymi ogromnymi zębami. Rany się zabliźniły, tkanki zrosły, ale brutalność tej ziejącej jamy pozostawała niezmienna ${ }^{82}$

Spojrzenie Innego, w którym odnajdujemy odbicie spójnego obrazu „ja”, w przypadku Édouarda potwierdza jedynie rozczłonkowanie, rozkład, rozpad,

81 P. Lemaitre Do zobaczenia w zaświatach, przeł. J. Polachowska, O. Hedemann, Albatros, Warszawa 2014, S. 195. 
gdyż nawet w oczach przyjaciela jego twarz jawi się jako nie-ludzka. Wkrótce bohater konstruuje piękne maski, pod którymi kryje swe zeszpecone rysy, nigdy nie nakładając tej samej maski dwukrotnie. Te fantazyjne maski charakteryzuje teatralny nadmiar - w ten sposób uwypuklają wyobrażeniowy charakter ego i rozszczepienie tożsamości ich twórcy. Ponadto anonimowa egzystencja, którą Édouard wiedzie w Paryżu, umarły dla rodziny i dla świata, sytuuje go poza porządkiem symbolicznym. Traci w ten sposób również kreowane przez Symboliczne złudzenie zakorzenienia tożsamości ludzkiej w kulturze. Trauma wojny stawia go twarzą w twarz z Realnym, które zwykle jest ukryte pod maską konwencji społecznych ${ }^{83}$. Można zatem zaryzykować stwierdzenie, że monstrualna rana Édouarda czyni z niego ucieleśnienie Realnego. Przywołując myśl Jenny Edkins, w powieści Lemaitre'a ontyczna trauma wojny, skierowana na konkretne byty, odkrywa bardziej ogólną traumę ontologiczna, która stanowi podstawę rzeczywistości społecznej ${ }^{84}$.

W Do zobaczenia w zaświatach dostrzec można również omówiony powyżej spór wokół czterech czynników, które zdaniem Alexandra definiują konstrukcję traumy kulturowej. Dążąc do upamiętnienia poległych, zapamiętanych jako młodzieńcy o pięknych ciałach, cywile okazują obojętność lub wręcz wrogość tym, którzy przetrwali kataklizm: „cały czas tak było, ci zdemobilizowani wciąż tylko nawijali o tej swojej wojnie, na okrągło wszystkich pouczali, człowiek zaczynał mieć już po uszy tych bohaterów. Prawdziwi bohaterowie byli martwi! A ci tutaj, też mi bohaterowie, akurat!" ${ }^{85}$. Co więcej, z tego punktu widzenia cywile narażeni na niedostatki w trakcie wojny byli równie poszkodowani jak walczący na froncie żołnierze. Poświęcenie weteranów traci więc jakiekolwiek znaczenie, dlatego Albert dochodzi do wniosku, że „jeśli chce się spokojnie żyć, lepiej schować do szuflady swoje galony zwycięzcy"86. Ubóstwo, degradacja społeczna, pogarda, utrata godności - oto losy bohaterów Lemaitre'a. W powstałej po wojnie hierarchii

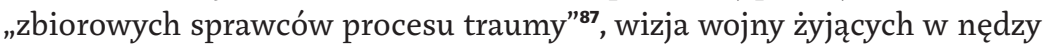

83 J. Edkins Trauma and the Memory of Politics, s. 66.

84 J. Edkins Time, Personhood, Politics, w: The Future of Trauma Theory: Contemporary Literary and Cultural Criticism, ed. by G. Buelens, S. Durrant, R. Eaglestone, Routledge, London-New York 2014, S. 132.

85 P. Lemaitre Do zobaczenia w zaświatach, s. 157.

86 Tamże, s. 158.

87 J.C. Alexander Trauma kulturowa i tożsamość zbiorowa, s. 205. 
weteranów zastąpiona jest przez inne, dominujące konstrukcje tożsamości zbiorowej. Cierpienie byłych żołnierzy nie istnieje w przestrzeni publicznej, a negując je, cywile wyrzekają się własnej odpowiedzialności za ich los, odmawiając im współczucia i pozostawiając ich w osamotnieniu ${ }^{88}$.W tym sensie Albert, a przede wszystkim Édouard, który sam siebie postrzega jako widmo, wpisują się w kategorię „zaginionych osób”, zdefiniowaną przed Edkins jako byt pomiędzy dwoma formami śmierci. Fizycznie są bowiem żywi, lecz nie mają żadnego bytu politycznego ${ }^{89}$. Trauma łączy się więc w tym przypadku z poczuciem bezsilności i zdrady ${ }^{90}$. Lemaitre odkrywa zatem, że wizja państwa narodowego jako źródła przynależności i jedności jest kojącą fantazją. Podobnie jak pełnia jednostki, harmonijna wizja demokratycznej wspólnoty jest jedynie wytworem Symbolicznego ${ }^{\text {91. }}$.

Ten stan wykluczenia z życia społeczno-politycznego, który za Giorgio Agambenem możemy określić jako „nagie życie”92, Édouard potrafi jednak paradoksalnie wykorzystać w sposób, który neguje bezsilność weterana. Obmyśla genialny plan, sprzedając pogrążonym w bólu Francuzom fałszywe projekty pomników i nagrobków, które nigdy nie zostają wybudowane. Skandal zostaje ujawniony w symboliczną datę 14 lipca, a hochsztaplerzy uznani za „złodziei pamięci"’3. Jeśli przyjmiemy, że artefakty upamiętniające zbiorową traumę prowadzą do ukojenia bólu, swego rodzaju społecznego „uspokojenia"94, cóż oznacza brak pomnika? Zemstę na tych, którzy wysłali żołnierzy na okrutną wojnę? Ironiczny sprzeciw weterana wobec instytucjonalizacji pamięci? Wobec nobilitacji zmarłych i idealizacji ich zmasakrowanych lub obróconych w nicość ciał? Czy może kontrapunkt uwydatniający, że trauma wymyka się reprezentacji? Wpisując wojnę w narrację narodowego heroizmu,

88 Tamże, s. 195.

89 J. Edkins Time, Personhood, Politics, s. 130.

90 J. Edkins Trauma and the Memory of Politics, s. 4. Zob. również A. Widera-Wysoczańska Istota traumy prostej i złożonej, w: Interpersonalna trauma. Mechanizmy i konsekwencje, red. A. Widera-Wysoczańska, A. Kuczyńska, Difin, Warszawa 2011, s. 38.

91 J. Edkins Trauma and the Memory of Politics, s. 94.

G. Agamben Homo Sacer. Suwerenna władza i nagie życie, przeł. M. Salwa, Prószyński i S-ka, Warszawa 2008.

94 J.C. Alexander Trauma kulturowa i tożsamość zbiorowa, s. 216. 
państwo ukrywa traumę, której samo jest sprawcą ${ }^{95}$. Aporia w powieści Lemaitre'a uwypukla lukę między wydarzeniem a jego przedstawieniem, lukę, w którą wpisują się konstrukcje traumy, tworząc spiralę roszczeń i znaczeń przypisywanych katastrofie przez różne grupy społeczne ${ }^{\mathbf{9 6}}$.

W interpretowanych powyżej utworach traumatyczne zranienie ma charakter zarówno fizyczny, jak i psychiczny, a źródłem traumy jest samo zdarzenie, ale również jego percepcja - intymna i publiczna. Weteran powraca codziennie do swej nierozpoznawalnej twarzy i nie potrafi odczytać jej znaczeń, a doznana przez niego przemiana stawia pod znakiem zapytania więź pomiędzy znaczonym a znaczącym oraz problematykę referencyjności. Odchodząc od uprzywilejowanego w literaturze zachodniej modelu traumy, zgodnie z którym wymyka się ona werbalizacji, Young, Barker, Dugain i Lemaitre tworzą linearne narracje, odnoszące się do konkretnych wydarzeń historycznych. Gueule cassée staje się w nich szczególnie pojemną metaforą - odbiciem zmasakrowanego krajobrazu ziemi niczyjej, symbolem okrucieństwa pierwszej wojny technologicznej, źródłem traumy jednostkowej, punktem wyjścia do rozważań na temat traumy kulturowej oraz tożsamości ludzkiej.

Ilustrując metamorfozę żołnierza pod wpływem traumatycznego doświadczenia nowoczesności, Young stawia przemoc i zagładę w centrum istoty człowieczeństwa, kreując jednak pozytywną wizję ocalenia. Barker natomiast eksploruje kryzys wizualny (afektywny, epistemologiczny, etyczny) wywołany przez powrót z frontu żołnierzy o okaleczonych twarzach. Trauma kulturowa łączy się tu zatem z dyskursem odrazy i niechęci, będącym wyrazem zbiorowego wyparcia tragicznych konsekwencji I wojny i jej odczłowieczającego potencjału. U pisarzy francuskich, Dugaina i Lemaitre’a, rana twarzy staje się bardziej upolityczniona, a tarcie różnych znaczeń przypisywanych traumie jest najbardziej uwypuklone. W La chambre des officiers oraz Do zobaczenia w zaświatach państwo jawi się jako wewnętrznie sprzeczna struktura; z jednej strony składa obietnicę jedności i bezpieczeństwa, z drugiej oparte jest na rzeczywistości przemocy, kontroli i przymusu. Dugain ukazuje walkę weteranów o uznanie stworzonej przez nich interpretacji rany oraz konstrukcję tożsamości zbiorowej opartej na traumie zbiorowej, izolacji i wykluczeniu. U Lemaitre'a natomiast I wojna jest przeżyciem ekstremalnym, które jednocześnie demaskuje iluzję porządku symbolicznego, zarówno na

95 J. Edkins Trauma and the Memory of Politics, s. xiv-xv.

96 J.C. Alexander Trauma kulturowa i tożsamość zbiorowa, s. 205. 
poziomie jednostki, jak i wspólnoty. Lemaitre posuwa swą refleksję na temat traumy zbiorowej i indywidualnej najdalej, zastanawiając się, czy trauma powinna stać się częścią czytelnych, kontrolowanych przez państwo praktyk upamiętniania, czy powinno się ją ująć bezkompromisowo, poza wszelką reprezentacją. Nasuwający się wniosek, że trauma I wojny bardziej domaga się przepracowania w społeczeństwie francuskim niż brytyjskim, wydaje się ryzykowny, analizowane obrazy literackie wskazują jednak bez wątpienia na potrzebę konfrontacji z tragedią wykluczenia gueules cassées i rekonceptualizacji należnego im miejsca w pamięci zbiorowej. Ludzie, których dotknęła trauma, dawno już nie żyją, lecz przetrwała ona w dyskursach kulturowych, a literackie narracje powstałe na ten temat sto lat później uwypuklają wachlarz nierozstrzygniętych roszczeń i afektów.

Psychologiczne, społeczne i polityczne znaczenia przypisane ranie twarzy omawianych powieściach (lub wich interpretacji) sąjednak również odbiciem fascynacji przełomu XX i XXI wieku. W kontekście francuskim i brytyjskim I wojna wydaje się nadal istotnym punktem odniesienia w refleksji na temat innych konfliktów XX wieku, w przemyśleniach dotyczących współczesnej tożsamości oraz w rozważaniach natury epistemologicznej, ontologicznej czy heurystycznej, charakterystycznych dla (post)modernizmu ${ }^{97}$. Otwarta twarz żołnierza stanowi w interpretowanych utworach emblematyczny obraz charakterystycznego dla późnej nowoczesności spektaklu, który wystawia na pokaz to, co ukryte, znosząc granice między wnętrzem a zewnętrzem ${ }^{\mathbf{9 8}}$. Trauma nasuwa tu refleksję na temat różnych kategorii wykluczenia oraz konstrukcji tożsamości osobistej i wspólnotowej. Treści przypisane traumatycznym przeżyciom okaleczonych żołnierzy w świecie przedstawionym interpretowanych utworów zdradzają rozterki jednostek przełomu XX i XXI wieku, uwikłanych w manipulacje suwerennej władzy, która nas kontroluje i ogranicza, lecz za które również ponosimy odpowiedzialnośćp9. Omówione powyżej utwory literackie pozwalają nam lepiej zrozumieć tragedię otwierającą wiek XX, jak i - sto lat później - rzeczywistość przez nią ukształtowaną, stając się odbiciem dręczących nas obaw i niepokojów.

97 Zob. S. Ouditt Myths, Memories, and Monuments: Reimagining the Great War, w: The Cambridge Companion to the Literature of the First World War, ed. by V. Sherry, Cambridge University Press, Cambridge 2005, s. 246. 


\section{Abstract}

\section{Anna Branach-Kallas}

NICOLAUS COPERNICUS UNIVERSITY (TORUŃ)

The Shock of the Great War: Individual Trauma, Cultural Trauma and the Representation of Gueules Cassées in Recent British and French Fiction

Branach-Kallas situates the concept of trauma in the context of World War I. She discusses cultural trauma theory, illustrating its basic characteristics with examples from the cultural history of the Great War. The article also analyses the representation of individual and cultural trauma in selected British and French novels by Louisa Young, Pat Barker, Marc Dugain and Pierre Lemaitre. The central figure of the facially disfigured soldier becomes an epitome of individual and cultural trauma, inspiring a critique of the nation-state and an exploration of (post)modern identities.

\section{Keywords}

The Great War, individual/cultural trauma, ethics and aesthetics, facial disfigurement, nation-state, exclusion 